\title{
Characterization of Short-Finned Pilot Whales (Globicephala Macrorhynchus) Population along the Caribbean Coast of Martinique
}

\author{
Flechet $A^{1}$, Pillet $\mathbf{M}^{1}$, Bordes $\mathrm{R}^{1}$, Morissette $\mathrm{L}^{2}$, Scanga $\mathrm{V}^{3}$ and De Montgolfier $\mathrm{B}^{1 *}$ \\ ${ }^{1}$ Aquasearch, ZAC Les Coteaux, Martinique, Canada \\ ${ }^{2} M$-Expertise Marine, Sainte-Luce, Canada \\ ${ }^{3}$ Aquasearch-Polynesie, Papeete Polynesie Française, Canada
}

*Corresponding author: De Montgolfier B, Aquasearch, ZAC Les Coteaux, 97228 Sainte-

Luce Martinique, Canada.

\begin{abstract}
The Caribbean coast of Martinique has a great wealth of marine mammals, with almost twenty species observed, including the short-finned pilot whale Globicephala macrorhynchus. Little is known about this specie in Martinique. Boat surveys between "le rocher du Diamant" and "l'îlet la Perle" allow gathering data and pictures. Statistical analysis, SIG and photo identification provide first information on the pilot-whale population. Results indicate there is a rather small but healthy population of G. macrorhynchus in Martinique. It is composed of both resident and migrant groups and no seasonality was observed. Correlation between the percentage of teenagers and the number of boats might imply an effect of whale-watching on individuals.
\end{abstract}

Keywords: Globicephala macrorhynchus; Short-finned pilot whale; Caribbean coast of Martinique; Population; Boat survey; Photoidentification

\section{Introduction}

Martinique Island, located in the Lesser Antilles, is surrounded to the east by the Atlantic Ocean and to the west by the Caribbean Sea. It is located in the middle of Agoa sanctuary, an MPA established in October 2010 by the French Government, that includes all Exclusive Economic Zones (EEZs) of French Antilles $(143256$ km [1]. This sanctuary, currently managed by the "Agence des aires marines protégées", implements measures for the protection of cetaceans. Over the last few years, coastal regions of Martinique were exposed to demographic growth and tourism [2,3]. Whalewatching is booming on the Caribbean coast of Martinique [4]. Tourism can bring some advantages such as revenue for local communities or an improvement of people's attitude toward the environment [5]. However, anthropogenic activities can impact marine mammals through environmental pollution, prey depletion or physical disturbances, especially in coastal areas [6].

In Martinique, whale-watching has been rapidly increasing over the past decade due to a stronger demand. Almost twenty species of marine mammals have been recorded in the Caribbean Sea [1]. For example, humpbacks whales (Megaptera novaeangliae), Bryde's whales (Balaenoptera bryde), toothed whales such as sperm whales (Physeter macrocephalus) and various species of dolphins (Stenella attenuata, Lagenodelphis hosei, Tursiops truncatus) are observed. Many of them, like the pantropical spotted dolphin (Lange et al., in prep) or the sperm whale [7], are increasingly studied.

Amongst all cetaceans of the Caribbean French Antilles, the short-finned pilot whale (Globicephala macrorhynchus, Gray 1846) is one of the less studied. This specie is found in all oceans and primarily distributed in warm waters [8-11], such as the Caribbean coast of Martinique. It is a highly gregarious species, travelling in socially cohesive groups from 10 to 50 individuals, but also encountered in large herds of several hundred [12,13]. Based on several studies, Globicephala sp. appear to live in relatively stable pods and not in fluid groups [10,14]. Pods generally contain individuals with close matrilineal associations [15,16]. Despite 
this, information on G. macrorhynchus is scarce in literature and its population trend is not well known [17].

Even if its northern Japan population is considered at risk, there is not enough data to evaluate its status elsewhere [11]. Due to this lack of data, the IUCN Red List of Threatened Species categorized the conservation status of this species as "data deficient" (IUCN). Moreover, this specie was principally studied in Japan $[6,18,19]$, in the archipelago of Madeira $[17,20]$, in the east coast of United States $[21,22]$, in Canary Islands [9,23,24] and in Faroe Islands [12,13] but has never been studied in Martinique nor in the Caribbean.

Agoa sanctuary is committed to the sustainable management of cetacean populations of this area [1], because they play an important role in marine ecosystem as top predators and affect the entire food-chain through trophic linkages [19]. Detailed knowledge on marine mammals' population, especially their movements, their survival rate or the pressures they are subjected to $[6,25]$, are crucial to effectively manage and preserve the entire marine ecosystem. Since G. macrorhynchus is more observed and often exposed, as demonstrated by Bordes [26], this study focuses on this specie for the first time in Martinique. Our aim is to characterize its population to enhance our knowledge about it.

\section{Materials and methods}

\section{Boat survey methods}

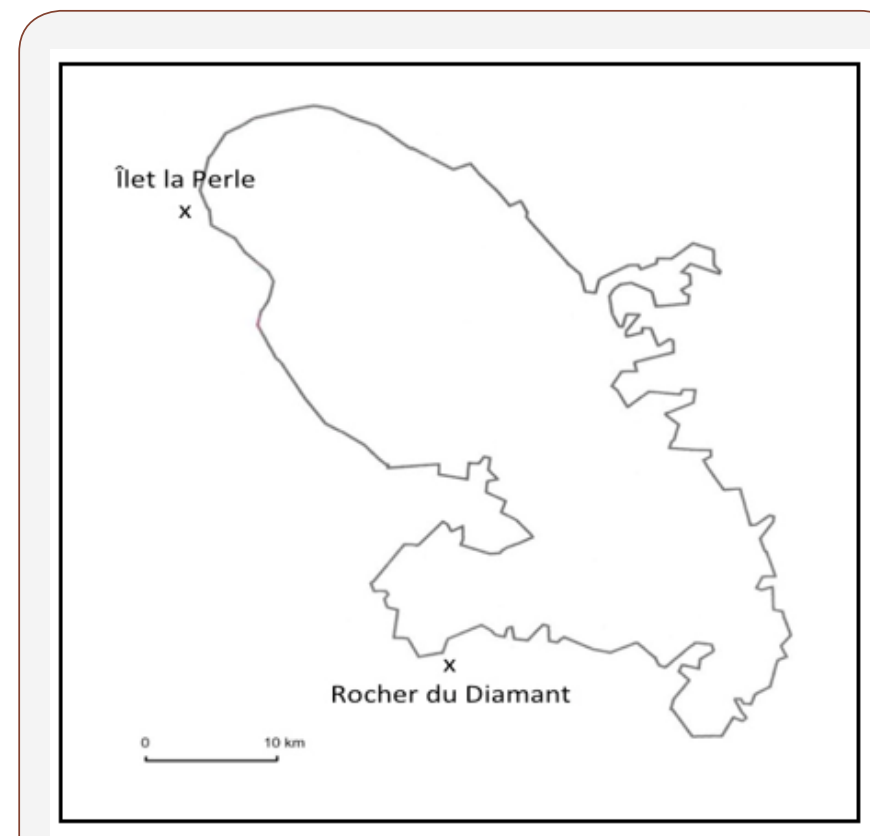

Figure 1: Map of the study area (modified form Google map).
From May 2013 to May 2015, boat surveys were conducted along the Caribbean coast of Martinique. The study area extended

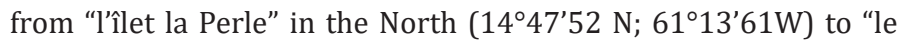

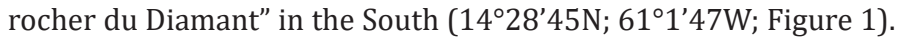
The area was covered $10 \mathrm{~nm}$ off the coast and was about $1296 \mathrm{~km}^{2}$.

Two different boats were used for this study: a 10 meters monocap, with a Volvo $340 \mathrm{hp}$ engine, equipped for 18 people on board, and a sailing catamaran, Lagoon 421, equipped for 20 people on board. Surveys were conducted several times each month (2 to 35 surveys per month; i.e. 378 surveys in total), from 8 am to 12 am with 2.5 hours of observation time.

For each observation of G. macrorhynchus, the following parameters were recorded: environmental conditions (sea state, wind speed, visibility, marine litter, and birds presence), group characteristics (GPS position, number of individuals, formation, calves presence, direction and speed of movement), ethological parameters (such as activity describe as resting, hunting, socialization or travelling) and interactions.

In parallel, pictures of dorsal fins were taken to identify individuals. Pictures were taken with different type of SLR camera.

\section{Data analysis}

GPS positions, data on the average number of individuals and their behaviors were analyzed using QGIS Wien 2.8 (Quantum GIS Development Team 2014, Quantum GIS Geographic Information System, Open Source Geospatial Foundation Project). This allowed visualizing the G. macrorhynchus distribution and their potential activity patterns in the study area.

Photo-identification relied on the presence of visible permanent markings used to recognize individual characters [27,28]. Indeed, in delphinids, the edge of the dorsal fin is often damaged (by predation or socialization) resulting in a unique profile $[9,28]$.

Pictures made during surveys were organized by date, species, picture number and selected according to their quality. Usable pictures were processed on Xnview editing software (Xnsoft, free software) to isolate the dorsal fins. Each dorsal fin was sorted in 4 categories: Q1, Q2, Q3 and Q4, representing the ease of identification of the dorsal and their reliability for identification Table 1, Q1 being the easiest to identify and Q4 the most difficult. Based on these rankings, a list of dorsal fins characteristics was performed. Dorsal characteristics of different dates were visually compared with each other to confirm initial sightings of individuals or re-sightings of known short-finned pilot whales.

Table 1: Ranking of dorsal fins, according to their ease of identification,

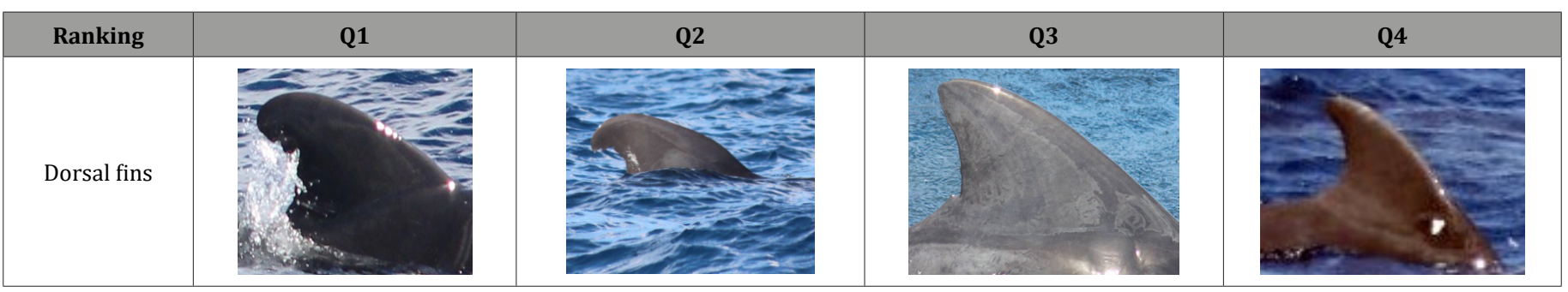

Q1 = very easy (quickly detectable),Q2 = easy, Q3 = difficult and Q4 = presence of tasks (need a photo analysis). 


\section{Statistical Analysis}

Presence index was calculated according to Diaz-Lopez [29], to obtain the number of observed individuals corresponding to the research effort. It was calculated as:

Presence index $=$ research effort $/$ number of observed individual

where the presence index represents the number of observed individuals per hour and the research effort is the time (in hour) dedicated to research.

Normality was verified by Kolmogorov-Smirnov test. Parametric (one-way ANOVA and Student t-test) or non-parametric tests (Kruskall-Wallis test and Mann-Whitney test) were then used depending if the distribution was accepted or not. When homogeneity of variance was present, a posteriori Tukey tests was used to compare means $(\alpha=0.05)$. If there was no homogeneity, a Fisher LSD test was used. Effects of season (spring, summer, autumn and winter) and tropical season (dry and wet) on the presence index of $G$ macrorhynchus observed during the 2 years study were tested.

The population was categorized into three classes of individuals, regardless of sexual dimorphism: calf (individual about $2 \mathrm{~m}$ ), teenager (individual with an intermediate size, between 2 and $6 \mathrm{~m}$ ) and adult (individual about $6 \mathrm{~m}$ ). Effects of season and activity on the different classes of individuals were tested too. Spearman correlations between percentage of adults, teenagers, calves and the number of boats were tested.

Finally, frequency tables were realized between behavior and different parameters (swimming direction, swimming speed, group formation, presence of bird and number of boats). Pearson Chisquare was used to assess if a relation was present between these variables. All statistical analyses were performed using Statistica 10.0 software (Statsoft, v.6.1, Tulsa, OK, USA).

\section{Results}

A total of 378 boat-based surveys were conducted during the study. 30 observations of G. macrorhynchus were realized during this time.

\section{Distribution}

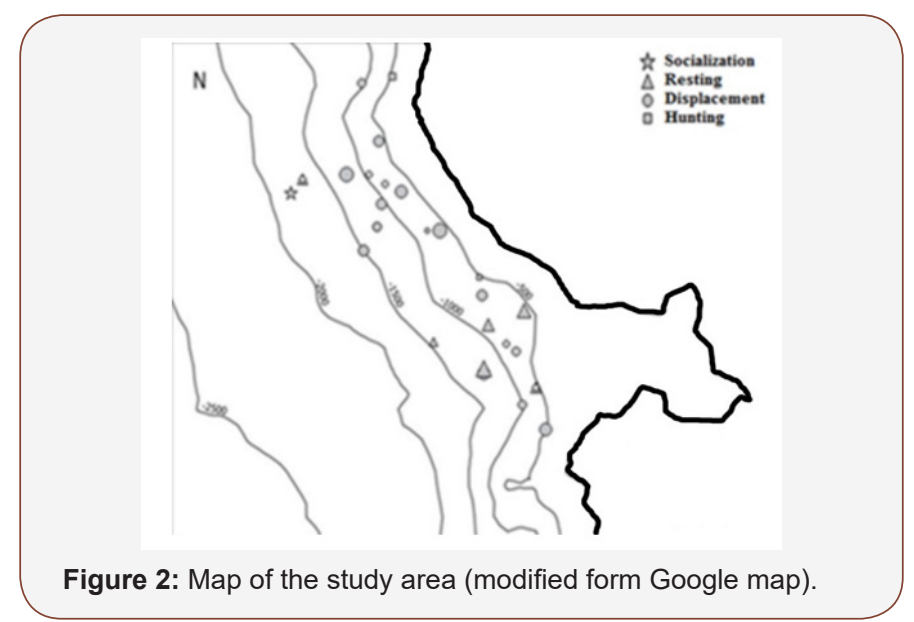

Individuals were observed from 500 to 2000 meters depth Figure 2. Resting activity was concentrated at the mouth of Fort de France. Finally, whatever the area, there were different group sizes, ranging from 10 to 35 individuals. Presence of G. macrorhynchus was noticed throughout the year, and not influenced by season $(\mathrm{p}=$ 0.44) nor tropical season ( $\mathrm{p}=0.47)$.

\section{Size and composition of the population}

Population size can be glimpsed with the calculation of a presence index. Thus, 30 observations of G. macrorhynchus were obtained after 945 hours of research effort. Presence index is 0.032 , a $3 \%$ chance, per hour, of observing a group of G. macrorhynchus, in the area. Each age class was observed very often. In $95 \%$ of cases, the observed group included calves (i.e. animal with $1 / 3$ size long of adult). Percentages of different classes were not influenced by season $\left(\mathrm{p}_{\text {adult }}=0.41, \mathrm{p}_{\text {teenager }}=0.82, \mathrm{p}_{\text {calves }}=0.81\right)$

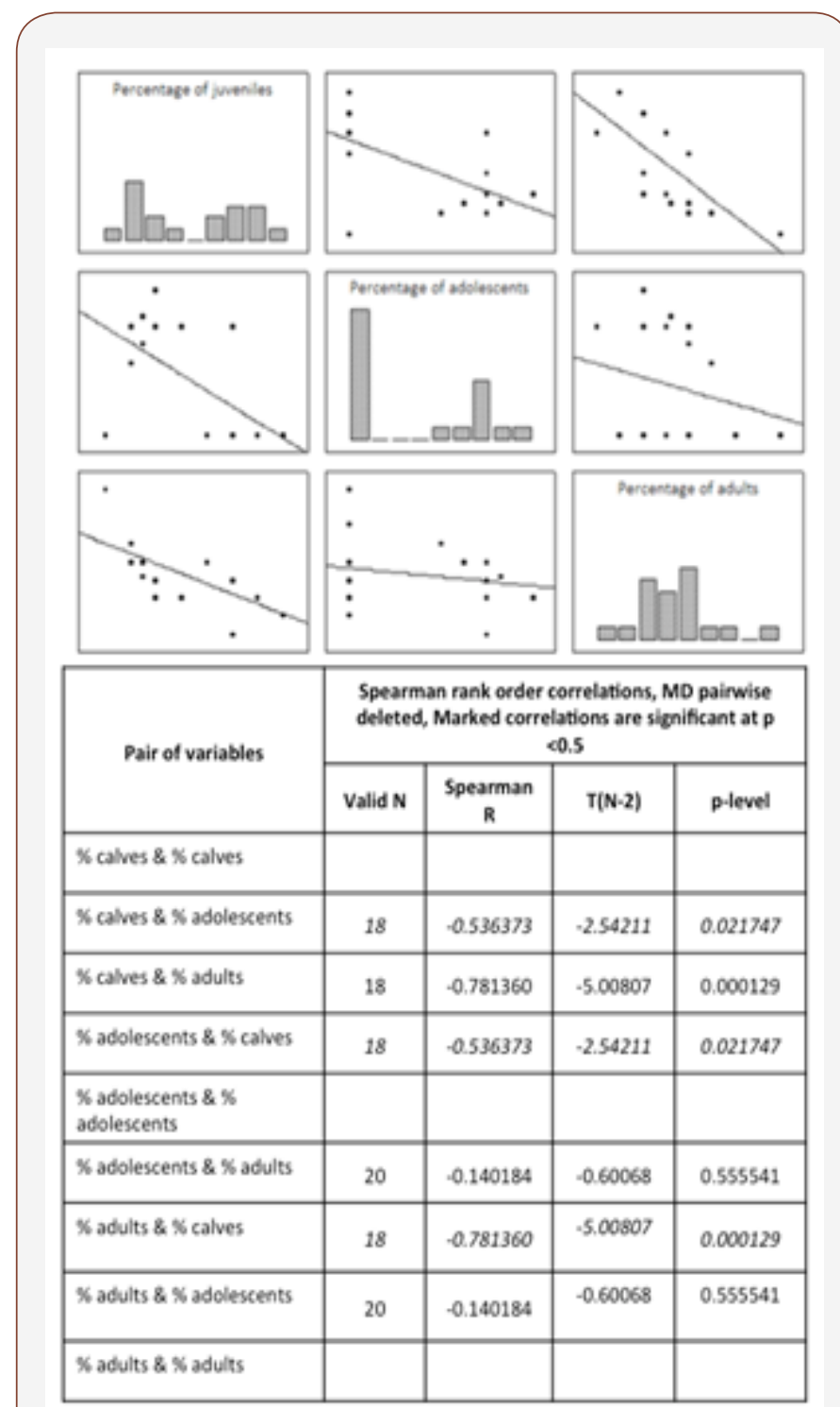

Figure 3: Histograms and correlation lines between the percentage of calves, adolescents and adults.

There is a correlation between the percentage of calves and adults $(\mathrm{R}=-0.78 ; \mathrm{p}<0.001)$ and between the percentage of calves and teenagers $(\mathrm{R}=-0.54 ; \mathrm{p}=0.02)$. However, the percentage of 
teenagers is not correlated with the percentage of adults $(R=-0.14$; $\mathrm{p}=0.55$; Figure 3$)$. There is a correlation between the number of boats and the percentage of teenagers $(R=-0.46 ; p=0.04)$, but not with adults and calves.

\section{Activities and movement}

The predominant observed behavior was traveling, with an occurrence of $65 \%$. Resting and hunting are sparsely observed behaviors, both representing $4 \%$ of occurrence Table 2. A correlation was observed between the behavior and the swimming direction of the group ( $p=0.018$; Figure 4). Thus, travelling generally performed towards south.

Table 2: Percentage of different behaviors observed.

\begin{tabular}{|c|c|}
\hline Behaviors & Percentage of observations \\
\hline Socialization & 24 \\
\hline Resting & 4 \\
\hline Hunting & 4 \\
\hline Travelling & 65 \\
\hline
\end{tabular}

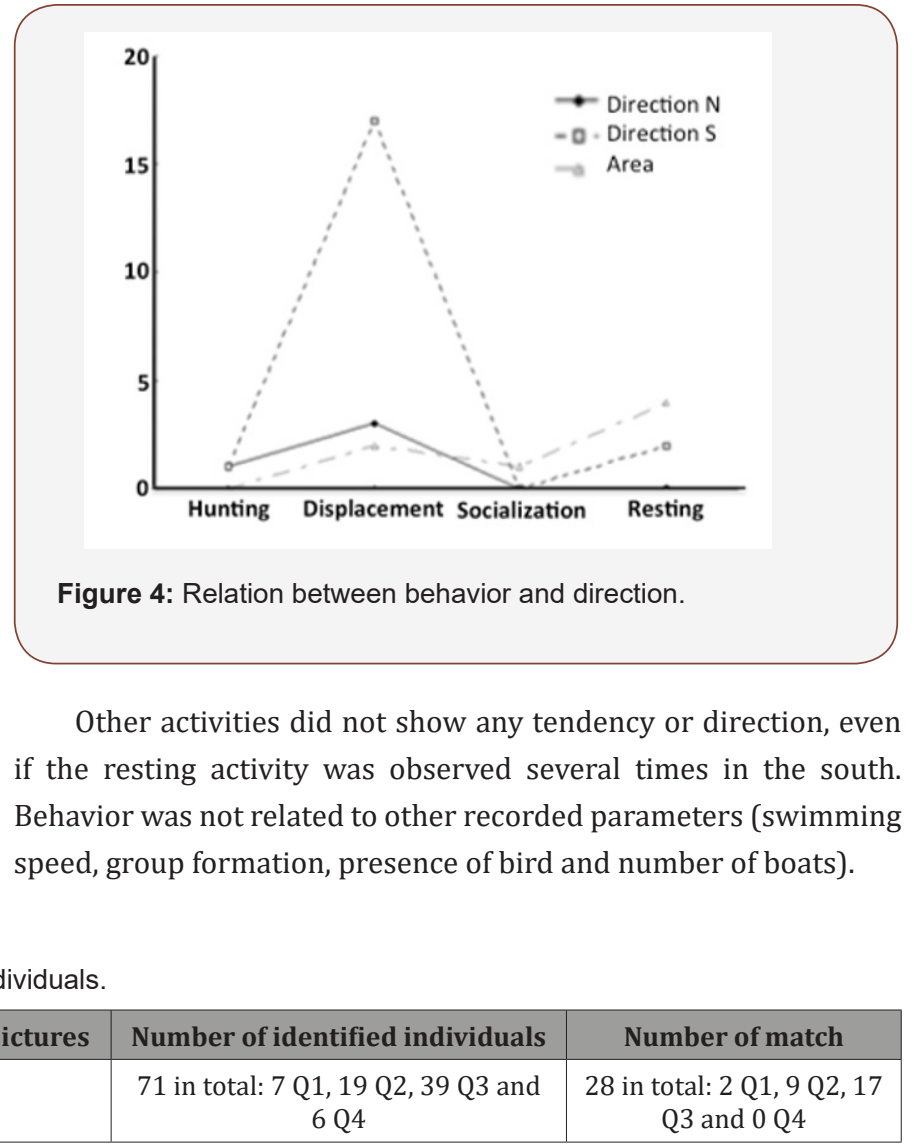

\section{Photo-identification}

Table 3: Summary of the photograph effort and the number of identified individuals.

\begin{tabular}{|c|c|c|c|c|}
\hline Species & Total numbers of pictures & Number of usable pictures & Number of identified individuals & Number of match \\
\hline $\begin{array}{c}\text { Globicephala } \\
\text { macrorhynchus }\end{array}$ & 1902 & 1134 & $\begin{array}{c}\text { 71 in total: 7 Q1, 19 Q2, 39 Q3 and } \\
\text { 6 Q4 } 28 \text { in total: 2 Q1, 9 Q2, 17 } \\
\text { Q3 and 0 Q4 }\end{array}$ \\
\hline
\end{tabular}

Table 4: List of individuals observed several times during the study.

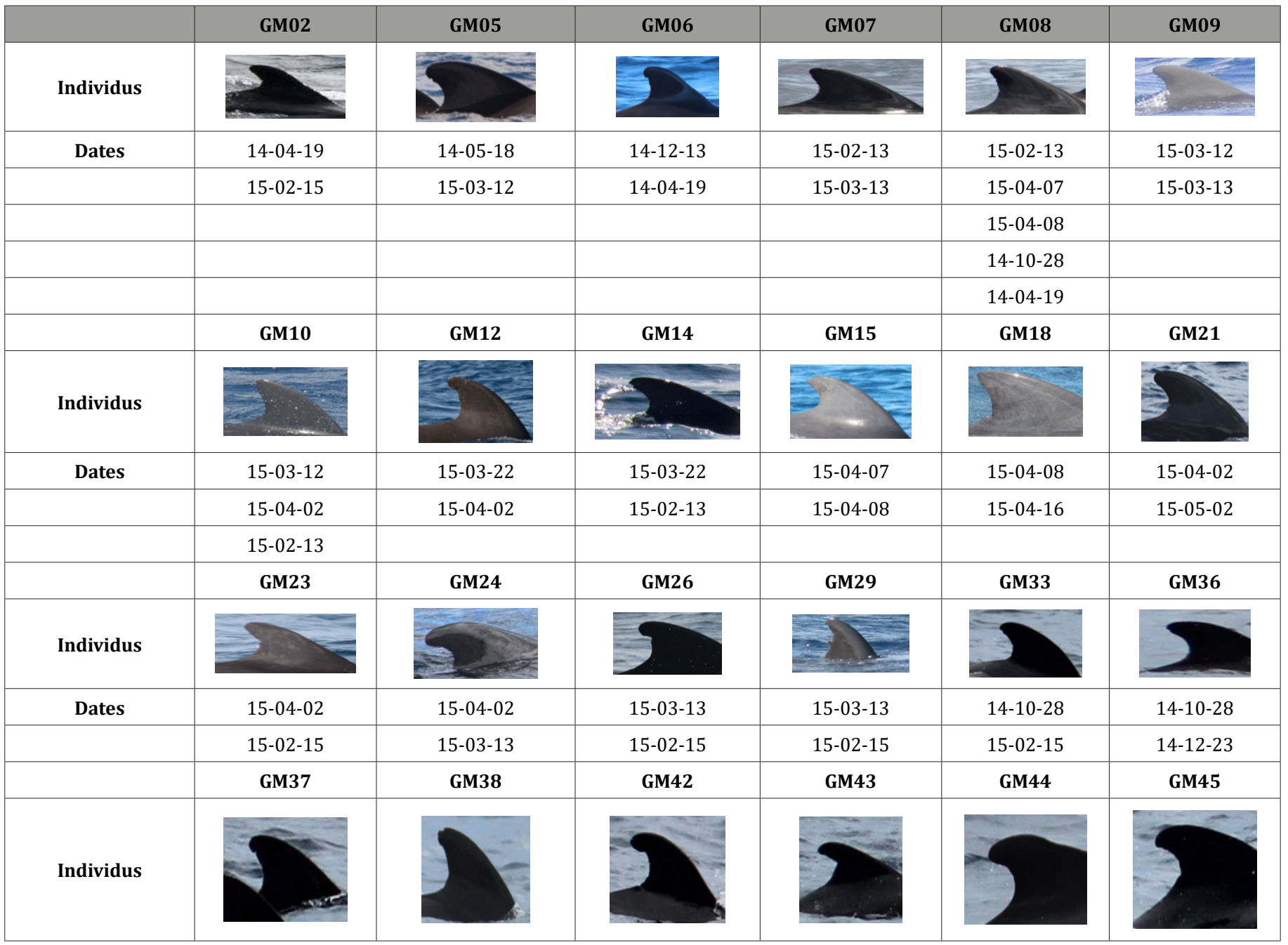




\begin{tabular}{|l|l|l|l|l|l|l|}
\hline Dates & $14-10-28$ & $14-10-28$ & $14-10-28$ & $14-10-28$ & $14-10-28$ & $14-10-28$ \\
\hline & $15-02-15$ & $14-04-19$ & $15-02-15$ & $15-02-15$ & $14-12-23$ & $15-05-02$ \\
\hline
\end{tabular}

Within the 1902 pictures taken during the survey, 1134 were used. On these pictures, 71 individuals were identified, most them classified as Q3 Table 3. Among all identified individuals, 24 were seen several times Table 4. Most of them were observed over the two years of observation. Moreover, individuals GM33, GM37, GM42 and GM43, and individuals GM36 and GM44, were seen together several times (at least twice).

\section{Discussion}

Along the Caribbean coast of Martinique, G. macrorhynchus population was essentially observed between isobaths of 500 and 2000 meters. This is in agreement with others studies around the world, describing that this specie is found in deep warm waters above the continental shelf $[22,30,31]$. This life off the coast can be explained by their feeding mode [30]. This species is known to feed mainly on cephalopods and occasionally on fish $[9,32,33]$. These preys are widely below $300 \mathrm{~m}$ deep, and some of them (Brachioteuthis riisei for example) can be caught up to 800 $\mathrm{m}$ [21]. For hunting, pilot whales swim on the water strip located above the 300 and $1000 \mathrm{~m}$ depth contour [30,32]. In our study, $4 \%$ of observations were hunting behavior, strict resting and socialization. In contrary, movement behaviors represent $65 \%$ of the observations. In fact, we mostly observed a slow movement behavior in surface water during our surveys. This observation supports the fact that the hunting activity is exclusively nocturnal [32]. In parallel, resting takes place at the mouth of the bay of Fortde-France. This quiet area could be considered as favorable for resting [34].

In our study, groups of G. macrorhynchus were composed of 10 to 35 individuals, sometimes with peaks of 100 to 200 individuals. This supports the observation of Stacey and Baird [11] and Bloch [13] indicating that pilot whales groups consist of 10 to 50 individuals. The presence index of G. macrorhynchus in our study was 0.032 (number of encounter/traveled distance) and for 100 $\mathrm{nm}$, the presence index is 0.16 . Those values are lower than those calculated for the long-finned pilot whale (Globicephala melas) in the Faroe Islands, north Atlantic [35,36], which is 0.41 to 0.70 per $100 \mathrm{~nm}$. G. macrorhynchus population observed in Martinique would rather be a small population.

Photo-id indicates that our population would be composed of resident group with the passage of migrating groups or different traveling groups usually passing on the Caribbean coast of Martinique. G. macrorhynchus is known as very gregarious, with a high degree of site fidelity and very stable groups [12,13,20,27]. Heimlich-Boran [9] defines members of a group of animals seen only once as migrants; and animals seen more than once, or in association, as residents. Both types were observed in our study. 71 individuals were identified, among them 24 were seen several times. Some individuals are observed over the two years in different seasons, with several underlying relationships.
Indeed, six adult individuals were identified several times together, which underlines links within the observed groups. It is probable, as in Alves [20] and Servidio [24] studies, that pilot whales encountered in the Caribbean coast of Martinique, belong to a single population encompassing several clans, with a clan of island whales and other clans of transients whales. The different clans may interact for mating and/or feeding purposes [20]. Managing both resident and migrant populations in the same region is difficult, due to the spatial overlap of resident and migrant and the resulting difficulty of estimating stock abundance [37]. For an efficient conservation management, a long-term monitoring is needed to know the number of animals using the area annually [17].

The distribution of G. macrorhynchus in Martinique was studied over a two-year period and showed no seasonality. This supports the observations of Alves et al. [17] in Madeira and of HeimlichBoran [9] in Tenerife. On the other hand, the Japan population has been shown to vary seasonally [18]. This seasonality may be due to a seasonal variation in male reproductive activity [18] or may depend on various factors such as prey distribution [12], underwater topography [38], water depth [39] and the ocean temperature $[40,41]$.

The difficulty to analyze free ranging animals in an open pelagic environment [17] and the large variation in our data, maybe due to the difference in study effort, can mask a seasonally trend and the decreasing presence of $G$. macrorhynchus in winter or wet season area.

During our study, the observed population was $95 \%$ of the time composed of calves, meaning the population is in very good health. The percentage of calf is linked to the percentage of adults and the percentage of teenagers. The link between adults and calves can be explained by the matrilineal social structure suggested by several authors for short-finned pilot whales $[9,18,42]$. However, we noticed that the percentage of calves decreased as the percentage of adults increase, or conversely. This is difficult to explain but two hypotheses can be proposed. Either there are more calves for the same number of adults, indicating variation in birth, like seasonality for reproduction $[9,18]$; or there are fewer adults for the same number of calves.

Our results also indicate that the percentage of teenagers is linked to the number of boats, this percentage decreasing as the number of boats increased. This could imply that teenagers were disturbed by a high number of boats and a negative impact of whale-watching on G. macrorhynchus. Little is known on the shortand long-term impacts of this kind of tourism on marine mammals [5]. However, a long-term monitoring is needed to evaluate the potential pressure on the animals [17], especially with the strong increase of whale-watching in Martinique.

To our knowledge, this is the first study on G. macrorhynchus in the Caribbean. As no information was available, we presented here 
first conclusion based on two years of surveys. More studies should be conducted to better understand the dynamic of this population. In parallel with the photo-identification of individuals, a catalog has been created. Comparison with other catalogs of Caribbean Islands could allow us to visualize the possible migration routes and learn even more on the travel of migrant groups.

\section{Acknowledgement}

The authors wish to thank MAM'S and Aliotis Plongée which allowed us on their boats. We are also grateful to the entire Aqua search team and their partners in Martinique for their assistance in the collection of pictures and data.

\section{Conflict of Interest}

The authors declare that no financial interest or any conflict of interest exists.

\section{References}

1. Gandilhon N (2013) Analyses des inventaires Agoa 2012 \& 2013. Agence des Aires Marines Protégées et Université des Antilles et de la Guyane.

2. Wilkinson C (2004) Status of Coral Reefs of the World: 2004. In: Australian Institute of Marine Science Press, Townsville, Australia.

3. Legrand H, Lenfant P, Sotheran IS (2012) Mapping marine benthic habitats in Martinique (French West Indies). Caribb J Sci 46: 267-282.

4. Constantine R, Brunton DH, Dennis T (2004) Dolphin-watching tour boats change bottlenose dolphin (Tursiops truncatus) behaviour. Biol Conserv 117(3): 299-307.

5. Kanaji Y, Okamura H, Miyashita T (2011) Long-term abundance trends of the northern form of the short-finned pilot whale (Globicephala macrorhynchus) along the Pacific coast of Japan. Mar Mammal Sci 27: 477-492.

6. Gero S, Gordon J, Carlson C (2007) Population estimate and inter-island movement of sperm whales, Physeter macrocephalus, in the Eastern Caribbean Sea. J Cetacean Res Manag 9: 143-150.

7. True FW (1889) Contribution of the natural history of Cetcea. A review of the family Delphinidae. Nat Mus Bull p : 36 .

8. Heimlich Boran JR (1993) Social organisation of the short-finned pilot whales, Globicephala macrorhynchus, with special reference to the comparative social ecology of delphinids. University of Cambridge, England.

9. Jefferson TA, Leatherwood S, Webber MA (1993) FAO species identification guide. Marine mammals of the world. Food and Agriculture Organization of the United Nations, Rome, Italy.

10. Stacey PJ, Baird RW (1993) Status of the Short-finned Pilot Whale, Globicephala macrorhynchus, in Canada. Can Field-Nat 107: 481-489.

11. Zachariassen P (1993) Pilot whale catches in the Faroe Islands, 17091992. Rep Int Whal Comm Special 14: 69-88.

12. Bloch D, Lastein L (1995) Modelling the school structure of pilot whales in the Faroe Islands, 1832-1994. In: Blix AS, Walløe L, Ulltang U (Eds.), Whales, seals, fish and man, Elsevier Science BV, Amsterdam, Netherlands, Europe, 4: 499-508.

13. Cañadas A, Sagarminaga R (2000) The northeastern alboran sea, an important breeding and feeding ground for the long-finned pilot whales (Globicephala melas) in the Mediterranean sea 16(3): 513-529.

14. Amos B, Barrett J, Dover GA (1991) Breeding behaviour of pilot whales revealed by DNA fingerprinting. Heredity 67: 49-55.

15. Culik BM (2004) Review of small cetaceans distribution, behaviour, migration and threats. Bonn, Germany.

16. Alves F, Dinis A, Nicolau C, Cláudia Ribeiro, Manfred Kaufmann, et al. (2015) Survival and abundance of short-finned pilot whales in the archipelago of Madeira, NE Atlantic. Mar Mammal Sci 31(1): 106-121.
17. Kasuya T, Marsh H (1984) Life history and reproductive biology of the short-finned pilot whale, Globicephala macrorhynchus, off the Pacific coast of Japan, Japan.

18. Kanaji Y, Okazaki M, Kishiro T, Miyashita T (2015) Estimation of habitat suitability for the southern form of the short-finned pilot whale (Globicephala macrorhynchus) in the North Pacific. Fish Oceanogr 24: 14-25.

19. Alves F, Quérouil S, Dinis A, Cátia Nicolau, Cláudia Ribeiro, et al. (2013) Population structure of short-finned pilot whales in the oceanic archipelago of Madeira based on photo-identification and genetic analyses: implications for conservation. Aquat Conserv Mar Freshw Ecosyst 23(5): 758-776.

20. Mintzer VJ, Gannon DP, Barros NB, Read AJ (2008) Stomach contents of mass-stranded short-finned pilot whales (Globicephala macrorhynchus) from North Carolina. Mar Mammal Sci 24(2): 290-302.

21. Rone BK, Pace IRM (2012) A simple photograph-based approach for discriminating between free-ranging long-finned (Globicephala melas) and short-finned (G. macrorhynchus) pilot whales off the east coast of the United States. Mar Mammal Sci 28(2): 254-275.

22. Aguilar Soto N, Johnson MP, Madsen PT, Díaz F, Domínguez I, et al. (2008) Cheetahs of the deep sea: deep foraging sprints in short-finned pilot whales off Tenerife (Canary Islands). J Anim Ecol 77(5): 936-947.

23. Servidio A (2014) Distribution, social structure and habitat use of shortfinned pilot whale, Globicephala macrorhynchus, in the Canary Islands. University of St Andrews, UK.

24. Tyne JA, Pollock KH, Johnston DW, Bejder L (2014) Abundance and Survival Rates of the Hawai'i Island Associated Spinner Dolphin (Stenella longirostris) Stock. 9(1): e86132.

25. Bordes R (2014) Impact de l'écotourisme baleinier sur le comportement des cétacés en Martinique: Application et suivi des règles de la Charte martiniquaise. Université de La Rochelle, France, p : 76.

26. Shane SH, Mc Sweeney D (1990) Using photo-identification to study Pilot whale social organization. Rep Int Whal Comm Special 12: 259-263.

27. Würsig B, Jefferson TA (1990) Methods for photo-identification of small cetaceans. Rep Int Whal Comm 12: 43-52.

28. Diaz Lopez B (2006) Interactions between Mediterranean bottlenose dolphins (Tursiops truncatus) and gillnets off Sardinia, Italy. J Mar Sci 63: 946-951.

29. Davis RW, Fargion GS, May N, TD Leming, M Baumgartner, et al. (1998) Physical habitat of cetaceans along the continental slope in the northcentral and western gulf of Mexico. Mar Mammal Sci 14(3): 490507.

30. Weir CR, Mac Leod CD, Pierce GJ (2012) Habitat preferences and evidence for niche partitioning amongst cetaceans in the waters between Gabon and Angola, eastern tropical Atlantic. J Mar Biol Assoc UK, 92: 17351749.

31. Baird RW, Borsani JF, Hanson MB, Tyack PL (2002) Diving and night-time behavior of long-finned pilot whales in the Ligurian Sea. Mar Ecol Prog Ser 237: 301-305.

32. Beatson E, O'Shea S, Stone EC, Shortland T (2007) Notes on New Zealand mammals 6. Second report on the stomach contents of long-finned pilot whales, Globicephala melas. N Z J Zool 34: 359-362.

33. AAMP (2010) Analyse stratégique régionale martinique: Enjeux et propositions de création d'aires marines protégées.

34. Buckland ST, Bloch D, Cattanach KL (1993) Distribution and abundance of long-finned pilot whales in the North Atlantic, estimated from NASS87 and NASS-89 data. Rep Int Whal Comm 14: 33-49.

35. Abend AG, Smith TD (1999) Review of distribution of the longfinned pilot whale (Globicephala melas) in the North Atlantic and Mediterranean. Woods Hole, Mass. U.S. Dept. of Commerce, National Oceanic and Atmospheric Administration, National Marine Fisheries Service, Northeast Region, Northeast Fisheries Science Center; Springfield, Virginia, USA. 
36. Conn PB, Gorgone AM, Jugovich AR, Barbie L Byrd, Larry J Hansen (2011) Accounting for Transients When Estimating Abundance of Bottlenose Dolphins in Choctawhatchee Bay, Florida. J Wildl Manag 75(3): 569-579.

37. Würsig B, Cipriano F, Würsig M (1991) Dolphin movement patterns: information from radio and theodolite tracking studies. In: Pryor K, Norris KS (eds) Dolphin Societies: Discoveries and Puzzles. University of California Press, Berkeley, p : 79-111.

38. Bernard HJ, Reilly SB (1999) Pilot whales Globicephala Lesson, 1828. In: Ridgway SH, Harrison R (Eds.), The second book of dolphins and the porpoises, Academic Press, San Diego, CA, USA, pp : 245-279.
39. Gaskin DE (1968) Distribution of Delphinidae (Cetacea) in relation to sea surface temperatures off Eastern and Southern New Zealand. N Z J Mar Freshw Res 2: 527-553.

40. Perrin WF (1984) Patterns of geographical variation in small cetaceans. Acta Zool Fenn 172: 137-140.

41. Oremus M (2008) Genetic and demographic investigation of population structure and social system in four delphinid species. University of Auckland, New Zealand. 